\title{
Religious Resistance to Family Law Reform in the US
}

\author{
Martha Albertson Fineman*
}

\begin{abstract}
This article traces the religious roots of American family law and the way that those roots still impact possibilities for and reaction to reform of law and the ways in which they shape contemporary politics in the United States. Traditional or fundamentalist religious conceptions of the family are incompatible with the three significant "revolutions" in social and cultural attitudes about women and gender equality that occurred in the United States during the latter part of the 20th century: the gender equality revolution; the sexual revolution; and the no-fault divorce revolution. As the changes in attitudes and behavior associated with these social movements were codified into laws governing the family, opposition and backlash have emerged. Today there are two ways in which this resistance is mobilized: the "Value Voter," whose influence in politics has greatly increased, particularly in the 2004 elections, and the social and academic movement known as the "Marriage Movement." The Marriage Movement is made up of religious conservatives, but also includes secular advocates for bringing back a more stable, less divorce friendly family.
\end{abstract}

\section{Introduction}

America is a deeply divided nation. We differ on such basic issues as how we should order our lives and the role of society and its institutions in shaping human behavior. We have divergent views on the importance of duty and obligation as contrasted with liberty and individuality. Various traditions, religious, cultural and otherwise, have produced very different and as strongly held beliefs. Caught in the cross hairs of this diversity is the American family.

The American family has changed dramatically, particularly over the past four decades, and these changes are reflected both in modern family law and

*Robert W. Woodruff Professor of Law, Emory Law School. 
in contemporary movements to alter that law. Social movements have organized around these changes that have goals that are in stark opposition to each other: one group seeking to use law to expand our ideas about the family and provide more people the benefits of family status, ${ }^{1}{ }^{1}$ the other mobilizing to remove innovations and steer society back to the more exclusive (and excluding) "morally-mandated" traditional family. Representing polar opposites in this struggle are the feminist approaches to family law reform, which is individualistic and rights-centered and fundamentalist rhetoric, which is steeped in religious imagery, symbols, and metaphors.

Our laws governing the American family emerged from, and thus reflect, a specific religious tradition. Some still see the family as religiously or divinely ordained and, therefore, unchangeable. Duties and responsibilities are set and established by an order higher than the individual, even superior to the state. In contrast, others see the family as based on individual expressions of love and happiness, an institution shaped thorough law and policy and, therefore, subject to manipulation and redefinition, certainly to evolution and change. ${ }^{2)}$

Those who think of family primarily in terms of individual happiness and satisfaction treat decisions such as whether to marry or not; engage in sexual relations or not and with whom; bear children or not, with or with out a partner-parent, as matters for individual and private determination unfettered by the imposition of majoritarian morality. It is not that an idea of family is unimportant to those who value the individual happiness over traditional duty. Rather the family is not viewed as an unalterable historic given, but as malleable, susceptible to social shaping and adjustment-an institution that can and should be adapted to reflect shifts in societal and individual preferences. Not surprisingly, those who hold this view tend also to believe that the laws that address marriage should do so separate from its religious origins. Accordingly, marriage is discussed primarily as an economic and

1) See Standhart v. Superior Court ex rel. County of Maricopa, 77 P.3d 451 (Ariz. App. 2003) (finding denial of access to marriage denied same-sex couples due process of law); See also American Bar Association Family Law Working Group on Same-Sex Marriage and NonMarital Unions, Analysis of the Law Regarding Same-Sex Marriage, Civil Unions, and Domestic Partnerships 23 (March 2005) (discussing state rights and protections afforded to same-sex couples) , available at http:/ / www.abanet.org/family/reports/WhitePaper.pdf.

2) See Goodridge v. Department of Public Health, 798 N.E.2d 941 (Mass 2003) (granting the right to marry to same-sex couples). 
social set of relationships, rather than as a sanctified status reflecting some divine purposes for the individuals involved.

On the other side of the cultural divide are those who hold deeply ingrained religious conceptions of the family. Marriage has theological significance-it is the foundation of the family and the family is both a reflection of divine order and the foundation of society. Consistent with its primary purpose, which is reproduction, marriage is the physical and spiritual joining of one man and one woman through a holy vow taken before God and man. Sacred texts reveal how family members should function in relation to each other. There is gender complementarity between husband and wife, as well as father and mother, with each sex having distinct, natural roles to play. Hierarchies are established, placing wives and children in obedient subservience to the head of the family. ${ }^{3}$ )

It sounds a bit antiquated to describe the American family in such a religious manner, particularly in a law review situation. However, while it is true that the United States is a modern and theoretically secular state, it is also a society in which marriage is far more important and politicized than it is in other societies. In thinking about the limits of family law reform in this society, it is also important to recognize that religion is far more central in our political discourse and policies than is true in many other Western democracies, particularly the European states. A distinction based on explicit mobilization of religious imagery and norms in political and legal rhetoric is found even in comparison with Canada and England, countries with which we share common legal and cultural history. In other contemporary advanced countries the rhetoric of international human rights norms now form the explicit background for discussions of domestic policies and articulation of governmental obligations. ${ }^{4)}$ In the family context, in a very real political sense, human rights norms have displaced historic ideas about family hierarchy and traditional roles. ${ }^{5)}$

3) See William Blackstone, Commentaries on the Laws of England 442 (1897); Frederick Pollock \& Frederic W. Maitland, The History of English Law 405-406 (2d ed. 1968).

4) Convention on the Elimination of All Forms of Discrimination against Women (hereinafter CEDAW), available at http://www.un.org/womenwatch/daw/cedaw/; Convention on the Rights of the Child (hereinafter CRC), available at http://www.unhchr.ch/ $\mathrm{html} / \mathrm{menu} 3 / \mathrm{b} / \mathrm{k} 2 \mathrm{crc} . \mathrm{htm}$

5) Perhaps human rights as an ethical and moral system of universal truths could be 
By contrast, in the United States resistance to human rights as an overarching measure for assessing internal law and policies seems particularly pronounced in regard to gender, sexuality, and family issues. ${ }^{6}$ ) Just as religious doctrines shaped our early cultural and social understanding of the American family, religious mandates inform the contemporary "family values" through which some argue today what is normal and what is deviant, as well as defining appropriate family roles for men, women, and children.")

In addition, it is important to realize that it is not only that we see ourselves as a traditional or conservative people that has deterred our acceptance of the concept of universal human rights as fully as other societies. Equally important is the fact that we tend to see our constitution as both superior and primary in defining American rights and responsibilities. The family is not mentioned in that document, which is focused on individual rights against governmental excesses and abuses. Federalism has mandated that the laws governing the formation and functioning of the family are appropriately the subject of local and individual state legislative and judicial concern. ${ }^{8)}$ When family relations have been brought before the Supreme Court, they are most likely treated as individual liberty or equality claims and resolved as such.9) Situations not susceptible to such an approach are either cloaked in the doctrine of family privacy ${ }^{10)}$ or remanded back to the local

understood to be a new, non-deity focused religion-one with a belief in individual equality and dignity at its core rather than the nature of the divine.

6) The U.S. has failed to ratify the CEDAW or CRC to date, objecting in part on religious grounds. See Catherine Powell, Lifting Our Veil of Ignorance: Culture, Constitutionalism, and Women's Human Rights in Post-September, 11 America, 57 Hastings L J. 331 (2005).

7) THE BOOK OF GenesIs (Genesis 2:24) (saying that the husband must leave his parents' house to find a wife "and they shall become one flesh").

8) Federal courts have traditionally abstained from hearing domestic relations cases. See Judith Resnik, "Naturally" Without Gender: Women, Jurisdiction, and the Federal Courts, 66 N. Y. L. REV. 1682 (1991).

9) See, e.g., Griswold v. Connecticut, 381 U.S. 479 (1965) (recognizing the right to privacy in the marital relationship.); Eisenstadt v. Baird, 405 U.S. 438 (1972) (extending the right to marital privacy to the individual: "if the right of privacy means anything, it is the right of the individual, married or single, to be free from unwarranted governmental intrusion ..."); Roe v. Wade, 410 U.S. 113 (1973) (finding that the right to privacy includes a woman's right to an abortion); Planned Parenthood of Central Missouri v. Danforth, 428 U.S. 52 (1971) (striking the state's requirement of spousal consent for married women and parental consent for minors to obtain an abortion). 
judiciary for resolution. ${ }^{11)}$ The resulting localization and fragmentation of family laws also impedes a coherent and focused approach to reform. There is no national family law with coherent norms and principles that can serve as a unified philosophy with which to engage and critique the backlash that has been mounted against recent reforms under the rhetoric of family values and the need to return to the natural family.

\section{Marriage and Religion}

The American marital entity has an interesting lineage as a legal category. It is directly tied to one religious set of concepts and beliefs forged in Ecclesiastical courts in England, which developed the laws that defined and regulated the legitimate family. ${ }^{12)}$ When family law moved to secular courts, as it did in England and the colonies, the understanding of what constituted a family and its relationship to the larger society was so defined by that religious beginning that it was difficult to separate out the secular for the religious meaning of family. Courts in the United States well into the 20th Century used religious imagery and mandates in resolving issues related to what was natural and appropriate intimate behavior and family formation. ${ }^{13)}$

10) A constitutional sense of family privacy is built on various legal presumptions, such as the deferral to parental rights in considering questions concerning children because parents are presumed to act in their children's best interest. See, e.g., Meyer v. Nebraska, 262 U.S. 390 (1923) (holding that parents have a right to direct the upbringing of their children, including control over the child's education); Pierce v. Society of Sisters, 268 U.S. 510, 534-5 (1925) (reiterating that the "liberty of parents and guardians" includes the right "to direct the upbringing and education of children under their control”); Prince v. Massachusetts, 321 U.S. 158, 166 (1944) ("It is cardinal with us that the custody, care and nurture of the child reside first in the parents."); Stanley v. Illinois, 405 U.S. 645 (1972) (recognizing the privacy right of parents to make decisions concerning the care, custody, and control of their children).

11) Federal courts have traditionally abstained from hearing domestic relations cases. See Judith Resnik, "Naturally" Without Gender: Women, Jurisdiction, and the Federal Courts, 66 N. Y. L. REV. 1682 (1991).

12) William Newill Montgomerie Geary, The Law of Marriage and Family Relations 1-6 (1892), available at http://books.google.com/books?id=3SsZAAAAYAAJ\&printsec =frontcover\&dq=the+law + of + marriage+and+family+relations\&ei=FnusSZLBHp2EzgT34NCQ BQ last visited March 2, 2009.

13) Bowers v. Hardwick, 478 U.S. 186, 196 (1986) (Chief Justice Berger concurring) 
Particularly incompatible with this religious family is the 20th century expansion of the ideal of equality to women, both in and outside of the family. The traditional family was based on gender difference and hierarchy in which men and women served preordained and complementary roles in a world divided into public and private spheres. ${ }^{14)}$

Historically, and in accordance with the church's approach to marriage, legal and other texts analogized the relationship between husband and wife to other "natural" hierarchical arrangements. Thus, a man was enthroned as head of the family, just as Jesus reigned as the head of the church, and the King was the head of the state. The respective positions of husband and wife were rigidly distinct and patriarchally ordered-husband's role, as frail wife's protector, was deemed "divinely ordained." Common law rules and regulations which eventually took over regulation of the family continued to aid in the construction and maintenance of subordinate gender roles in the family. The structure of the common law mired married women, in particular, in family responsibility and left them on a legal plane far from access to independent and autonomous decision making. ${ }^{15)}$

Among the religious mandates that found expression in law was that of marriage as a life-long sexual union blessed and sanctified by God, whose purpose was procreation. Laws prohibiting sexual relations outside of marriage reinforced its preferred position. ${ }^{16)}$ In addition, family relationships reflected the hierarchical organization of religious society. Authority over children in the common law family was fairly extensive. Its justification was founded upon the necessities of parental responsibility.

There was a direct connection between the English state religion and the legal treatment of intimate relationships. Marriage was a sacrament administered by the church and subject to its rules. Under the common law system in effect in England until fairly recently (as legal institutions go), issues concerning the creation and dissolution of marriage and other aspects of family formation were left to the ecclesiastical courts. ${ }^{17)}$ It was not until the

("condemnation of those practices is firmly rooted in Judeo-Christian moral and ethical standards. Homosexual sodomy was a capital crime under Roman law").

14) Linda Hirshman \& Jane Larson, Hard Bargains: The Politics of Sex 123 (1998).

15) Id.; See also 1 William Blackstone, Commentaries on the Laws of England 442 (1897).

16) Lawrence M. Friedman, A History of American Law 60-65, 179-86 (1973).

17) William Newill Montgomerie Geary, The Law of Marriage and Family Relations 1-12 
passage of the Matrimonial Causes Act of 1857 that jurisdiction over marriage and divorce was transferred to civil courts.

Consistent with the precepts of their religious approach, marriage was viewed as a life-long commitment by these English courts. An annulment or, failing that, desertion, was virtually the only routes out of an unhappy union. The Church of England's ecclesiastical courts could grant a divorce "from bed and board" which allowed couples to live apart, but not remarry. Divorce was theoretically available, but only through a special Act of Parliament, and between 1800 and 1836, an average of three such bills of divorce were granted each year. Generally, access to divorce was limited until the late twentieth century. ${ }^{18)}$

This view of the presumed permanence of marriage was also evident in colonial America where divorce could be granted by a secular judiciary, but this rarely happened. In fact, prior to the mid-twentieth century in the United States, judicial divorce, although increasingly more common over time than in the colonial period, was available only for "cause."19)

An "innocent" spouse could ask the state to sever the marital tie when she or he was successful in demonstrating the "fault" of her or his mate. Fault grounds indicated there had been some egregious offense to the very marital union. At that time, states such as New Hampshire only permitted divorce for very serious offenses that were considered to undermining the nature of the marital connection, such as adultery. ${ }^{20)}$ Other states considered the amorphous category of "cruelty" to be a sufficient basis for dissolution. Colonial divorce laws varied considerably by region, and the northeastern states tended to be slightly more liberal than their southern neighbors. ${ }^{21}$ )

In the United States there was no established state religion but the relationship between religious perceptions and beliefs about marriage and the

(1892), available at http://books.google.com/books?id=3SsZAAAAYAAJ\&printsec =frontcover\&dq=the+law+of+marriage+and+family+relations\&ei=FnusSZLBHp2EzgT34NCQ BQ (last visited March 2, 2009).

18) $I$.

19) For an overview of traditional fault grounds in divorce, see HOMER H. CLARK, JR. \& ANN Laquer Estin, Cases and Problems on Domestic Relations 656-659 (7th ed. 2005).

20) New Hampshire Public Statutes, Chapter 175, 5 (1901).

21) See Lee E. Teitelbaum, Cruelty Divorce Under New York's Reform Act: On Repeating Ancient Error, 23 BufF. L. REv. 1 (1973). 
construction of state principles regarding that connection was still evident, if attenuated. The individual states incorporated common-law concepts and definitions from the religiously-shaped English rules into their laws governing family. American judges tracked the religious rhetoric of their English counterparts when considering issues involving the family.

Divine laws governed family relationships, setting out the natural order for the individuals who entered them. ${ }^{22}$ The content of the marital relationship was also divinely structured. In what has become one of the most famous concurrences in the American legal tradition, in the 1873 Supreme Court case of Bradwell v. Illinois, 83 U.S. 130, 141 (1972), Justice Bradley made what is still considered the classic statement regarding the common law perception of the divinely determined distinct roles of husbands and wives:

... the civil law, as well as nature herself, has always recognized a wide difference in the respective spheres and destinies of men and woman. Man is, or should be, woman's protector and defender. The natural and proper timidity and delicacy which belongs to the female sex evidently unfits it for many of the occupations of civil life. The constitution of the family organization, which is founded in the divine ordinance, as well as in the nature of things, indicates the domestic sphere as that which properly belongs to the domain and functions of womanhood. The harmony, not to say the identity, of interest and views, which belong, or should belong to the family institution is repugnant to the idea of a woman adopting a distinct and independent career from that of her husband. So firmly fixed was the sentiment in the founders of the common law that it became a maxim of that system of jurisprudence that a woman had no legal existence separate from her husband, who was regarded as her head and representative in the social state ...

22) See, e.g., Loving v. Virginia, 388 U.S. 1, 3 (1967) (the trial judge's opinion stated "Almighty God created the races white, black, yellow, Malay and red, and he placed them on separate continents. And but for the interference with his arrangement there would be no cause for such marriages. The fact that he separated the races shows that he did not intend for the races to mix..."); Potter v. Murray City, 760 F.2d 1065, 1070 (10th Cir. 1985), cert. denied, 474 U.S. 849 (1988) ("monogamy is inextricably woven into the fabric of our society. It is the bedrock upon which our culture is built"). 
As this quote so clearly illustrates, the marital family - the "traditional family" of the common law and the Church of England-was defined by distinct and hierarchical roles across gender.

The organization of the traditional family in the British and American legal tradition was also patriarchal with the husband - "head" of the family - owed obedience and domestic and sexual services from his wife. In return, he was obligated to support her and their children. ${ }^{23)}$ The husband's role conferred rights as well as responsibilities, including the right to punish family members. Since he bore responsibility for their actions, a husband had the right to reasonably chastise both wife and children. His support obligations also gave him a corresponding right to the earnings of his wife and children, and to control over their property. ${ }^{24)}$

Further, the view of marriage expressed by Justice Bradley and the divinely-ordained respective positions of the spouses also limited the expectations and opportunities for married women in the larger society. The marital family's hierarchically-organized and well-defined gender roles placed the spouses in different spheres. Women, excluded from many of the public aspects of life, were perceived as appropriately dependent. As the Bradley concurrence in Bradwell expressed, their true calling was considered to be the home and family. ${ }^{25)}$

This ordering of domestic life was intuitive-responsive to the natural dependency of women. Common law-imposed disabilities on women supported this ordering of the world. Married women were not able to own property or make contracts. In some instances they could not even be held responsible for their own torts or crimes. Their husbands, perceived as controlling them absolutely, were charged instead. ${ }^{26)}$

The common law expressed a structure in which the distinct specialization of the spouses complemented each other - the wage earner and the housewife; the protector and the protected; the independent and the dependent. Each spouse needed his or her complement in order to attain and

23) See Jessie Bernard, The Good-Provider Role: It's rise and Fall, 16 Am. Psychol. 2-10 (Jan. 1981).

24) William Blackstone, Commentaries on the Laws of England 442-445 (1897).

25) Bradwell v. Illinois, 83 U.S. 130, 141 (1972).

26) See William Blackstone, supra note 24. 
maintain a whole, complete family entity; an entity that provided for all its members' needs. This specialization, bringing together the head and the heart of the family in the form of husband and wife, allowed the marital family to function in a self-sufficient manner, providing both economic and domestic resources to the unit.

In regard to parents and children the law was also clear and clearly reflected differentiated roles and natural hierarchy. William Blackstone in his Commentaries on the Laws of England declared:

"The power of parents over their children is derived from the former consideration, their duty; this authority being given them, partly to enable the parent more effectually to perform his duty, and partly as a recompense for his care and trouble in the faithful discharge of it .... [t]he power of a parent by our English laws [is] sufficient to keep the child in order and obedience. He may lawfully correct his child, being under age, in a reasonable manner; for this is for the benefit of his education." (p. 452)

References to "parents" in this context should be understood in light of the further admonition by Blackstone, in the same chapter, that he was discussing the "legal power of a father (for a mother, as such, is entitled to no power, but only to reverence and respect) ..." (p. 453).

James Kent's Commentaries on American Law [1827] shows how this version of a gendered and authoritarian family also took root in the US:

"In regard to wives - the husband acted as her guardian, and was bound to maintain her. Therefore "the law has given him a reasonable superiority and control over her person and he may even put gentle restraints upon her liberty if her conduct be such as to require it ...." (p. 181)

State v. Rhodes, 61 N.C. 453, 454 (1868), set out the role of family privacy, which abandoned both subservient wife and child to discipline and possible abuse:

“The courts have been loath to take cognizance of trivial complaints 
arising out of domestic relations ... the evil of publicity would be greater than the evil involved in the trifles complained of .... however great are the evils of ill temper, quarrels, and even personal conflicts inflicting on temporary pain, they are not comparable with the evils which would result from raising the curtain and exposing to public curiosity and criticism the nursery and the bed chamber."

In the United States, the moral or divine sensibilities swirling around that early common law history have tended to endure and the family in both the arenas of form and function is viewed by many Americans as a "natural" entity, pre-dating and existing independent of the state.

\section{Revolutions and Reforms}

Many of the explicitly religious laws regulating the family in the United States have substantially changed over time. The law now reflects the image of a more egalitarian set of expectations in regard to husband and wife, one that reflects a commitment to gender equality that resonates in the broader culture. These changes in perception about the family arose along side of other transformations during the 1960s and 1970s in which the constitutional principle of anti-discrimination fashioned in the civil rights movement was extended to establish gender equality.

In fact, during the mid-20th century, America experienced three intertwined "revolutions" in beliefs and practices that altered patriarchal social and legal constraints on women in the name of gender equality. These revolutions together provided a countervailing ideology with which to challenge the traditional family relationships. The transformations in expectation and aspiration that occurred changed not only the way we understood the family, but also the way we understood the relationship between men and women, as well as between the State and the individual. Cumulatively, in freeing women (and men) from historic disadvantages associated with gender and family roles these revolutions redefined society. In doing so, they also led to rewriting the terms of legal or civil marriage in ways that are incompatible with the historic religious mandates.

The demise of the ideal of indissolvable marriage that accompanied no- 
fault divorce was certainly dramatic from the legal perspective. Divorce is now more accessible-undermining the religious idea of life-long union. ${ }^{27)}$ More profound and threatening, however, was the fact that the internal order of the marital relationship was revised. Traditional lines of authority were disrupted and women viewed as equals, even as competitors with men, disturbing the preexisting and gendered hierarchical order.

\section{The Gender-Equality Revolution}

The gender-equality revolution has proven of particular importance in shaping the new views on marriage. Ideals of gender equality drastically altered women's aspirations for themselves, both in and outside of the family and the way to realize these new aspirations was enforced through law. ${ }^{28)}$ Women's relationship to the "public sphere" was reshaped and they are now in the workforce, expected to be self sufficient, engage in paid work (even if they are mothers with caretaking responsibility), and generally assume equal responsibility for the economic well-being of themselves and their families on a par with men.

Feminism recognized that the "private sphere" also had to change. Old family patterns had to be reformed with laws freeing women mired in family roles and responsibilities. Advocacy of gender-equality in the workplace was accompanied by advocacy for reform of traditional family law. As a result, the legal relationship between husband and wife has been completely rewritten in gender-neutral, equality aspiring terms. Modern divorce rules reject the image of the wife as a dependent of her husband due to her preordained domestic roles. Spouses are now seen as full and equal marital partners. ${ }^{29)}$

This turn to equality within the family has had tremendous economic

27) Part of the traditional wedding ceremony was the admonition from the religious figure officiating that what "God hath joined together let no man put asunder" (Matthew 19:6).

28) See, e.g., Equal Pay Act of 1963, Pub. L. No. 88-38, 77 Stat. 56 (June 10, 1963) codified at 29 U.S.C. § 206(d) (abolishing wage differences based on sex); Title VII of the Civil Rights Act of 1964 (Pub. L. No. 88-352, 78 Stat. 241 (July 2, 1964), codified at 42 U.S.C. § 2003 et seq. (prohibiting discrimination by covered employers on basis of race, color, religion, sex or national origin).

29) See Uniform Marriage and Divorce Act $§ 308$, 9A U.L.A. (pt. 1) 446 (1998); AMERICAN LaW Institute, Principles of the Law of Family Dissolution: Analysis and Recommendations $§ 5.04$ (2002). 
implications. The idea of alimony - the ongoing economic obligation on the part of the husband for the support of an innocent wife ${ }^{30)}$ - has been rejected in favor of [rare] awards of temporary financial maintenance until training for the workplace can be completed and economic self-sufficiency attained. ${ }^{31)}$

In addition, novel concepts were developed in order to redefine the economic nexus between husband and wife in regard to property. The idea of "contribution," broadly defined to include domestic labor, replaced title and cash contributions to the accumulation of property, savings, and retirement accounts. Property is now perceived as the product of marital or joint labor, not only of individual efforts. Property is divided along guidelines that presume more or less equal value, even if the contributions are different in kind. $^{32)}$

Interestingly, gender equality also facilitated an individualization of family law in regard to contracts between the couple. Increasingly, couples are allowed to define for themselves the specific economic consequences of a dissolution using pre-marital agreements. The idea that women are in need of state protection because they are unable to bargain or negotiate as equals has been replaced with the notion that everyone should be free to contract and hold to the bargains they reach prior to marriage regardless of how unfair those bargains may seem at divorce. ${ }^{33)}$

In addition to altering the economic relationship between spouses at divorce, gender equality provisions now govern arrangements about children. Child custody determinations are no longer based on inappropriate and outdated definitions of gender-roles. Gone is the "tender years" presumption

30) Alimony is a form of spousal support awarded to the dependent spouse upon divorce that provides a standard of living favorable to the economic circumstances that existed during the marriage. See Mani v. Mani, 869 A.2d 904, 909 (N.J. 2005) ("somehow, with the passage of time, the distinction between true divorce and mere separation was obliterated and alimony began to be awarded in all cases. No rationale was advanced to explain why parties, who were no longer married, remained economically bound to one another").

31) See sources cited supra note 29.

32) Id.; Under the common law system the spouse who earned the money owned the property and alimony was the way to address the on-going economic dependency of wives. Consistent with complementary gender-roles, the custody of children went to their mothers if they were of "tender years." Older children were presumed appropriately placed with the parent of the same sex so they could learn how to become men or women.

33) See, e.g., sources cited supra note 29. 
that referred mothers for the custody of very young children. Parents are presumed equally able to care for their children, with no gendered assumptions legally permitted. ${ }^{34)}$

\section{The Sexual Revolution}

Also setting the stage for the changes in the family as a legal and cultural entity was a significant shift in the way that society thought about pre-marital sex. Of course, people have always had sex outside of marriage, but such behavior was received differently for men and women. The attitude for male non-marital sexuality was "boys will be boys," while women's indulgence was viewed with stigma and societal condemnation. The gender equality revolution and the development of the birth control pill altered this to some extent. $^{35)}$

In addition, when marriage was legally held to be essential to society, criminal laws were in place to protect marriage by making other sexual relations punishable. Laws against fornication, adultery, and non-marital cohabitation made marital sex the only legal sex in many states. ${ }^{36}$ Civil law was equally harsh on the unmarried. Landlords and employers were free to deny access and benefits to those "living in $\sin ^{237)}$ and children born outside of marriage could be discriminated against by state and local welfare systems. ${ }^{38)}$ Same sex relationships were even more harshly punished in the criminal law. ${ }^{39)}$

As a result of the sexual revolution many people are able to view sex, even reproduction, as decisions that an individual could make independent of

34) Devine v. Devine, 398 So. 2d 686, 695 (Ala. 1981) (holding "that the tender years presumption represents an unconstitutional gender-based classification which discriminates between fathers and mothers in child custody proceedings solely on the basis of sex").

35) See Beth Bailey, Prescribing the Pill: Politics, Culture, and the Sexual Revolution in America's Heartland, J of Social History, Vol. 30, No. 4, 827 (Summer 1997).

36) See Lawrence M. Friedman, A History of American Law 60-65, 179-86 (1973)).

37) See Matthew J. Smith, The Wages of Living in Sin: Discrimination in Housing Against Unmarried Couples, U.C. DAvis L. Rev. 1055, 1056 (1992).

38) Kenneth J. Neubeck \& Noel A. Cazenave, Welfare Racism: Playing the Race Card AgAinst AMERICA's PoOR 5, 86, 164-165 (2001).

39) Bowers v. Hardwick, 478 U.S. 186 (1986) (deciding that a Georgia sodomy law that criminalized oral and anal sex between consenting adults). 
marriage. As a result, we have experienced an increase of instances of nonmarital motherhood. We also see a growing visibility and increased acceptability of same-sex relationships. Non-marital cohabitation, both for same and heterosexual couples has exploded. Cohabitation is also seen as a real alternative to marriage for many, not just a part of an engagement or premarital trial period. ${ }^{40)}$

The sexual revolution has drastically altered the nature of state intervention into intimate sexual relationships. No longer involved in prohibiting and policing these arrangements, the state has increasingly come under pressure to give committed, marriage-like relationships the same benefits and privileges as are attached to formal marriage. ${ }^{41)}$ Courts and legislatures grapple with the implications of attaching marital consequences to marriage-like relationships. ${ }^{42)}$

As the state has moved away from monitoring and regulating sexual relationships, individual privacy and liberty interests ascend. These concerns replace or dilute ideas about traditional morality and virtue in public and legal discourse. Certainly marriage has lost its exclusivity in regard to sexuality and reproduction, both in practice and, for many, as a matter of principle or ideology.

\section{The No-Fault Divorce Revolution}

At the beginning of the 1960's most states had various grounds under which an innocent spouse could seek a divorce from a guilty spouse: adultery was the universal-considered a violation of the marital commitment. Other grounds included extreme cruelty, willful desertion, willful neglect, habitual intemperance, incurable insanity, and conviction of a felony. Reflecting the

40) See Renata Forste, Prelude to Marriage or Alternative to Marriage? 4 J.L. \& FAM. STUD. 91-92 (2002); See also Richard J. Gelles, Contemporary Families: A Sociological View 176-178 (1995).

41) See, e.g., Baehr v. Lewin, 852 P.2d 44(Haw. 1993) (holding that prohibition of same-sex marriage constituted a form of sex-based discrimination); Goodridge v. Department of Public Health, 798 N.E. 2d 941 (Mass. 2003) (permitting same-sex marriage).

42) See Baker v. State, 744 A.2d 864 (Vt. 1999) (deciding that legislative action was needed to issue marriage licenses to gay couples); See also Opinions of the Justices to the Senate, 802 N.E.2d 565 (Mass, 2004). 
adversarial nature of the divorce process and the substantive need for an innocent victim there were also defenses to divorce. These were things like connivance (complicity), collusion (consent), condonation (forgiveness) and might also include equitable defenses such as delay in bringing suit. Once fault had been proven if the defendant failed to establish an adequate defense, the plaintiff was released from their marital obligations and entitled to a decree of dissolution or divorce. ${ }^{43)}$

Late in the 1960's, the California Legislature enacted a law that established a no-fault system of divorce in which the grounds for marital dissolution were 'irreconcilable differences which have caused irremediable breakdown of the marriage." ${ }^{44)}$ It quickly became apparent that the determination that a marriage was irretrievably broken could only be a subjective judgment and that if one spouse asserted this to be the case it was, even if the other is convinced that this marriage can be saved. ${ }^{45}$

Accompanying the no-fault revolution was a different type of adjustment, one no less significant for altering the way that we view marriage and divorce in the United States. Changes in the rules governing the economic consequences of divorce evolved in the decades after no-fault came into being on a grand scale. ${ }^{46)}$ The idea of separate property for assets accumulated during the marriage disappeared and was replaced with marital property. Spousal support awards were increasingly disfavored unless someone was unable to work for pay. The ideal of gender equality transformed the expectations for divorcing wives and facilitated the transition from a fault based system by establishing rules that were argued to enable courts to manage the economic fallout from divorce.

43) See Herbert Jacob, The Silent Revolution: The Transformation of Divorce Law in the United StATES, 30-7 (1998).

44) Lawrence Friedman, Rights of Passage: Divorce Law in Historical Perspective, 63 Or. L. Rev. 649 (1984) (citing the RePORT OF THE GOVERnoR'S COMMISSION ON THE FAMILY, issued in 1966).

45) Even today many are critical of the unilateral aspect of no-fault divorce and there are attempts to make the agreement of both spouses required, particularly if there are children.

46) I document the transition in rules governing property and spousal support in THE Illusion of Equality: The Rhetoric and Reality of Divorce Reform (University of Chicago Press, 1991). 


\section{Implications of the Three Revolutions}

Reform in family law in the United States often rises out of religion, even when groups claim to be secular. Religious imagery infused American law from its roots in the ecclesiastical courts of England, and the American view of family cannot be extricated from its religious origins. ${ }^{47}$ As the United States becomes more religiously diverse and religion becomes one of many competing belief and value systems, issues of religion become increasingly contestable, with many believers standing more firmly on their religion than their earlier counterparts. ${ }^{48)}$

The changes in law that have followed in the wake of the three revolutions (gender-equality; sexual; no-fault divorce) have made entry into and exit from marriage a matter of individual preference, a decision relatively unfettered by state regulation and control. No-fault divorce laws shifted control over the continuance of a marriage from the state to the couple (or one of them).

In fact, all the revolutions share a perspective built around the individual as the relevant unit of social policy and law. Individual consent and individual choice, not the mandates of marital status, are what is relevant in these revolutions and the family law reforms based upon them. This shift in emphasis, which reflects a transformation in societal attitudes as well, is as significant as the specific content of the law reforms. Previously, the family as an essential societal entity trumped the individual interests of its members. Individual happiness was thought to be appropriately submerged in the wake of family responsibility and obligation.

Reflecting the profound change in their position in society, marriage is no longer considered to be an economic imperative for women. As the virtual abolition of alimony indicates, women are expected to work and be selfsupporting. Preservation of marriage by limiting divorce was no longer considered necessary. Gender equity and antidiscrimination law liberated women from the imposed economic dependency on husbands by giving them

47) Berman, Harold J. Law and Revolution: The Formation of the Western Legal Tradition 226-230 (1983) (describes the development and operations of the canon law of marriage).

48) Horwitz, Paul. Religion and American Politics: Three Views of the Cathedral 6 (2008), available at http:/ / ssrn.com/abstract=1267445 (last visited Oct. 2, 2008). 
access to the paid workforce, education, and political life. ${ }^{49)}$ The evaporation of earlier conceptions about the natural dependency and incapacities of women substantially undermined one of the traditional secular justifications for state control over marriage and divorce. ${ }^{50)}$

As the new emphasis in family law indicates, divorce is the occasion for adjusting the spouses' economic entanglement. Dissolution entails division of marital property and an economic rendering of partnership justice. If women are now presumed to be equals capable of both bringing home the bacon as well as frying it up in a pan, marriage can no longer be legitimated as necessary to remedy their dependency. ${ }^{51)}$

Other basic beliefs about the centrality of marriage to the ordering of society have also been called into question. For example, if children are increasingly being raised in single-parent homes shouldn't society turn attention to supporting those units, rather than continue to build policy around the marital family? ${ }^{52)}$ Further, asserting marriage as the essential structure for caring for children seems disingenuous when statistics indicate that many children in two-parent families are living in poverty or without adequate health insurance, even with both adults working. Single parenthood does correlate with many social and economic disadvantages for children, but the fact of single-parenthood itself does not negatively affect the well being of children, but it may be that being raised in a disadvantaged environment does. ${ }^{53)}$

In fact according to a large, multiethnic study at Cornell University school readiness was found to be about the same in large samples of single and two parent families, suggesting that what matters is the parent's own abilities and educational level in a single-parent family. ${ }^{54)}$

49) Harrington, Mona. Women, the Values Debate, and a New Liberal Politics. Dissent, Vol. 52, Issue 1, at 86-87 (Winter 2005).

50) $I d$.

51) In 1997 the Bureau of Labor Statistics estimated that $53.4 \%$ o fall households had two income earners. Steve Teske, Number of Dual Income Families Continues Growing. BLS REPORTS. Daily LAB ReP. (BNA) No. 99 at D3 (May 22, 1998).

52) This is the question that I explore in Wood Wetzel \& JAnice, The Neutered Mother, The Sexual Family (and Other Twentieth Century Tragedies) (Routledge Press 1995).

53) Lang, Kevin \& Jay L Zagorsky. Does Growing Up with a Parent Absent Really Hurt? Journal of Human Resources, Vol. 36, Issue 2, 253, 253 (Spring 2001).

54) Ricciuti \& Henry, Single Parenthood and School Readiness in White, Black, and Hispanic 6- 


\section{Backlash}

As changes in behavior and in the legal perception of the family have occurred, proponents of religious orthodoxy in the United States have reacted as though religion itself was threatened. It is not just the possibility of new forms of the family that seem particularly dangerous - the fear is also attached to the perception that religion is being displaced by an even more secular framework. Resistance to secularism seems to be a key feature of American fundamentalism. Therefore, it is not surprising that there is vigorous resistance by some segments of the religious community to the movement to expand the definition of the legal family, as well as condemnation of shifting family behavior that would make the institution of marriage more egalitarian and flexible.

Since the natural (or religious) family is primary to fundamentalist religions, it is not surprising that reforms that move us away from that family to the more modern egalitarian model generates corollary resistance and condemnation. It is also not surprising that in the United States the rhetoric and energy of this backlash motivates politics and informs policy debates. The backlash has both strength and breadth. It comes primarily from two somewhat overlapping, sources: the Value Voter and the Marriage Movement.

Value-voters believe the family is under siege by those who do not value it and who would violate it for political ends. ${ }^{55}$ The language of their counter offensive is often explicitly religious in nature. The siege must be addressed on a variety of fronts. Marriage is central-it provides the way for now-rampant

and 7-Year-Olds, 13 Journal of Family Psychology 450 (1999).

55) See George Lakoff, Moral Politics: How Liberals and Conservatives Think (metaphor used througout the book) (2001 ed., University of Chicago Press). Lakoff uses the family as a metaphor. Conservatives are the strict father and liberals the nurturing mother. The parents in this case had different beliefs associated with this basic division, holding two different concepts of morality. Not only do these two disagree with each other they each find the other side incoherent. Family is also a metaphor for country; the way we understand our country with the government corresponding to the parents and individual citizens to children. The way we understand how a family will be tells us how we understand how a country should be. Here I look more at struggle around the family and its control by the government, how that has changed and reformed in developing family law. 
illicit sexuality to be contained. It also has as its primary (and divine) purpose the birth and raising of children, a purpose that must again be elevated as supreme and supported by law. In the world-view of the typical value-voter marriage is a set and established institution-its definition is not open to question or redefinition. The state's mandate is to protect marriage in its historic form as a lifelong commitment between one man and one woman joined by God and state.

In this line of argument, the state's interest in marriage is based foremost on its role as the foundation for the family, which is posited as the basic building block of society. Threats to marriage are threats to the whole idea and place of family and, therefore, promise to bring destruction and chaos to the larger society. The duty of the state is to shape public policy in ways to protect marriage and family, mostly by promoting traditional two-parent marital families. ${ }^{56)}$

The suggested mandates are numerous. Divorce must be discouraged, if not outright prohibited. ${ }^{57)}$ We must regulate and contain sexuality; hence marriage would be the only relationship in which sexual expression can legitimately take place. The state therefore should reenact and enforce now abandoned historic restrictions on non-marital sexuality, such as adultery and fornication statutes. Of course, sodomy should be re-criminalized.

Also reproduction must be brought back and safely encapsulated within marriage - this is certainly the only legitimate relationship in which reproduction should occur. This belief would justify harsh measures designed to make unmarried mothers wed and mothers contemplating divorce stay married. Non-procreative sex should be discouraged. Sex education left to the family, except that abstinence should be officially advocated in schools and elsewhere. Certainly abortion would be illegal.

From among a cluster of such value issues in recent times same sex marriage has emerged as the most shrill and [historically effective] battle cry for the value-voter. ${ }^{58)}$ But it is not the only rallying point. It is important to

56) National Commission on Civic Renewal, A Nation of Spectators: How Civic Disengagement Weakens America and What We Can Do About It 13 (1998).

57) Council of Civil Society, A Call to Civil Society: Why Democracy Needs Moral Truth 19 (1998).

58) The latest success was the 2008 passage of Proposition 8 in California, which set aside the 
note that value-voters are alarmed by a wide range of issues that challenge the traditional reproductive family unit of husband and wife. In their narrative of crisis the underlying culprits responsible for the social and cultural decline are feminism, with its resistance to feminine or wifely and motherly duties and roles, and secular humanism, with its relativist approach to morals and values.

The cultural lines were clearly drawn along designated pro and anti family lines which played out in the 2004 election. Writers for the Religious News Service announced that "the stronger-than-expected role of moral values in [the 2004] election signals that the nation's values agenda is likely to be dominated by 'social morality" not 'social justice' in the coming years. ${ }^{59)}$

The morality troops have been amassed. The NY Times reported "for the past four years, Mr. Bush has been deliberately assembling the building blocks of a formidable faith coalition. Pastor by pastor, rabbi by rabbi, and often faceto-face, Mr. Bush has built relationships with a diverse range of religious leaders." ${ }^{60)}$ John Green, an expert on religion and politics and director of the Bliss Institution of Applied Politics at the University of Akron concluded that the Bush coalition included a much larger group of more traditional religious people, many of them outside of the evangelical tradition. He noted that "what they did have in common is that all of these groups tend to hold traditional views on sexual behavior:" $\left.{ }^{\prime 11}\right)$ There seemed to be a consensus among religious writers that the Bush's strategy of appealing "to the social conservatives in [a variety of religious] groups who felt alienated and disrespected by a popular culture that in their minds trivializes religion" in fact paid off.

Of course, during this period Democrats anxiously argued that the terms

state Supreme Court's determination that denial of marriage to same sex couples violated the state constitution. Also relevant are the passage of various state constitutional amendments and Defense of Marriage Acts at both the national and state levels that seek to bar same-sex marriages from recognition.

59) Kevin Eckstrom \& Michelle Melendez., Moral Values Top Voters Concerns - But What does it Mean? CHRISTIANITY TODAY, Nov. 1, 2004, available at http://www.christianitytoday.com/ct/ 2004/novemberweb-only/11-1-42.0.html.

60) Laurie Goodstein \& William Yardley, Bush Benefits from Efforts to Build a Coalition of the Faithful. N.Y. TIMES. November 5, 2004, at A19.

61) Id. 
"values" and "morals" can mean different things to different people. Liberal commentators were busy reminding everyone of the Christian or moral values that condemn unjust war and mistreatment of the poor and helpless. However, as John Green argued, typically "when ordinary people think of morality, they think of traditional sexual morality ... they don't think of social justice." ${ }^{62)}$ Republican pollster, Bill McInturff, labeled "garbage" the speculation that the category moral values was "flawed" and made it seem as if cultural matters had a more powerful effect than they actually did. McInturff asserted "people who picked moral values as an issue know what it means ... it is a code word in surveys for a cluster of issues like gay marriage and abortion. He continued that if the term 'moral values' was really the "catchall" Democrats asserted with a confused meaning then more Democrats would have picked it. Noting the overwhelming Bush support among the value-voters, McInturff observed the moral values label "is self-selected by people for whom these issues are very important for their votes." He also argued the now-standard opinion that the margin by which Bush carried these value-voters arguably made the difference in the election. ${ }^{63)}$

The election of 2008 should not make those alarmed by the role of religion in 2004 feel too relieved. Religion and family values were also very important in that most recent Presidential race. The irony was that it was the Democrat who was the family values candidate. Barack Obama, with his picture-perfect family, clearly upstaged John McCain on the issue of faith and values. McCain was hardly an appropriate poster-boy from the values perspective in any case. $^{64)}$

Yet, according to Mr. Green's most recent study, through the summer of 2008, McCain did have the support of much of the same religious base that voted for George W. Bush in 2004. The major shifts towards voting Democrat

62) See Kevin Eckstrom \& Michelle Melendez, supra note 59.

63) Jim Rutenbert, Poll Question Stirs Debate on Meaning of 'Values', N.Y. TIMES, November 6, 2004, at A11.

64) Nicholas D. Kristof, McCain and His First Wife. N.Y. TIMEs, July 11, 2008, available at http://kristof.blogs.nytimes.com/2008/07/11/mccain-and-his-first-wife/. McCain divorced his first wife after she stayed with him during his imprisonment in Vietnam and his struggles thereafter when she was injured in a car wreck and gained weight. It is also possible that he began pursuing Cindy during his first marriage, and he has used the resources of his new family to enhance his political career. 
occurred in the Black Protestants, Latino Protestants, Latino Catholics and Traditionalist Catholics. Unaffiliated religious people, secular people, Jewish people, and people from other world religions supported Obama over McCain as well by differing margins. ${ }^{65)}$ Value votes may not have played as prominent a role in the 2008 election as they did in the 2004 election, but arguable religion still did play a role.

Interestingly, Paul Horwitz of the University of Alabama School of Law analyzed Obama's 2006 speech on the place of religion in American politics in comparison to speeches by two other presidential candidates, John F. Kennedy and Mitt Romney. Obama argues that Democrats should not avoid addressing issues of religion, as they historically have done, because such avoidance "fails to acknowledge the power of faith in ... the lives of the American people." ${ }^{66)}$ This is a mistake that conservatives have not made according to Obama, and progressives must "tap into the moral underpinnings of the nation" and acknowledge that religious people in American cannot be expected to separate their morality from politics, especially when law in the United States is a codification of morality, mostly Judeo-Christian, as Obama points out. Horwitz notes that Obama's speech "represents a fuller level of engagement between religion and politics on the political side of the ledger. Rather than simply enlist on one side of the culture war to build a "voting majority of the faithful"67) or the faithless, Obama emphasizes the importance of engagement on both sides: the need to "tackle head-on the mutual suspicion that sometimes exists between" both "religious America and secular America." ${ }^{68)}$

Religion and value voters are not the only story, however, and certainly not the most unsettling. Complementing the religious advocates for a return to a more traditional family world is an eclectic movement often referred to as the Marriage Movement. It can be viewed as a loose confederation of

65) John C. Green, The Fifth National Survey of Religion and Politics: A Baseline for the 2008 Presidential Election, Results Embargoed until 3 PM, September 19, 2008.

66) See Sen. Barack Obama, Call to Renewal, Keynote Address, June 28, 2006, available at http:/ / www.barackobama.com/2006/06/28/call_to_renewal_keynote_address.php (hereinafter Obama).

67) Horwitz at 57 citing David Brooks, Faith vs. the Faithless, N.Y. TimEs, Dec. 7, 2007, at A31.

68) Id. at $57-58$. 
groups - some religious, but others secular-whose rhetoric reflects moral, often based on social scientific, bases for reestablishment of the primacy of marriage ${ }^{69)}$ Central to these arguments are the need for societal stability and concern for the wellbeing of children raised by single parents.

Those groups forming this coalition come in different forms and have different motivating beliefs, many are overtly political. Some have specific groups in mind that are in need of attention and protection given the rates of divorce. In this category would be child advocates, men's groups who oppose no-fault divorce, and fathers' rights groups. Some are organized to affect a specific, often religious, view of marriage. Included in this group would be the Marriage Savers, ${ }^{70)}$ as well as the One Million Man March organization. There is both an anti-gay marriage movement component ${ }^{71)}$ and a pro-gay marriage

69) Opposition to cultural and social changes in beliefs about marriage has not only been generated through resort to religious language. The opposition has also been aided by certain social science information. This complements the activities of organizations associated with churches, such as "Marriage Savers" and such information allows them to make secular assertions as part of the efforts to lessen or eliminate divorce. Some churches now refuse to perform marriages unless the couples agree to a waiting period that involves clergy counseling. Such practices reflect the efforts of The National Council on Family Relations, which created the Healthy Marriage resource Center that produced social science evidence that premarital counseling and preparation aids marriages and prevents divorces.

KatHeRINe SHAW SPAHT, The Modern American Covenant Marriage Movement: Its Origins and Its Future, in Comparative Perspective, in covenant Marriate in Comparative Perspective (John Witte JR., and Eliza Ellison Eds., 2005) supra note 6, at 239-48, at 239-243.

See generally the following:

Institute for American Values, The Marriage Movement: A Statement of Principles, available at http://www.americanvalues.org/pdfs/marriagemovement.pdf (2000); Institute for American Values, Why Marriage Matters: Twenty-One Conclusions from the Social Sciences, available at http:// www.americanvalues.org/pdfs/wmmexsumm.pdf (2002); Does Divorce Make People Happy? Findings from a Study of Unhappy Marriages, available at http://www.americanvalues.org/ UnhappyMarriages.pdf (2002).

Benjamin Scafidi, Principal Investigator, Institute for American Values, The Taxpayer Costs of Divorce: First Ever Estimates for the Nation and all Fifty States 5 (April, 2008), available at http://newstage.healthymarriageinfo.org/docs/costofdivorce.pdf.

(Postulating that marriage reduces crime, poverty, and their burden on the justice system among aiding in other areas).

70) The boast is that Marriage Savers-Community Marriage Policy ${ }^{\circledR}$, signed by churches, helped 10,000 clergy of 220 cities reverse the culture's high divorce rate. The group's webpage announced: "There's a different kind of good neighbor policy, a new movement of saving marriages by turning to the power of church and community."

71) Kay \& Herma Hill, From the Second Sex to the Joint Venture: An Overview of Women's 
movement.

These diverse groups coalesce around the promotion of marriage and advocacy of a traditional two-parent home as the superior child-rearing unit. Agreement at those two levels does not reflect unity on opposition to samesex marriages. Indeed, many Marriage Movement supporters would welcome the infusion of true believers into the marriage cause that opening it up to same-sex couples would provoke. The consensus that unites is around the belief that marriage and two-parent households are superior and should be supported in law and policy.

The marriage movement has some interesting intersections with the valuevoter. While it may not view family in exactly the terms dictated by fundamentalist religion and would probably not resort to arguments based on divine will, many in the Marriage Movement do incorporate rhetoric of morality when extolling the virtues of the traditional family. There is an academic wing of the Marriage Movement that to some extent mimics and replicates family value arguments for return to a traditional and religiously inspired marital family. It does so through a discourse of secular, socialscientific arguments in favor of two-parent family that asserts its superiority has been proven and justifies harsh treatment for those who reject this proof.

This group of academics is well-positioned. They have and do serve as political and policy advisors and they have been influential at both the federal and state governmental levels. Along with much more conservative commentators, these academics believe that the marital family is a foundational institution - the "cradle of citizenship" - that teaches "standards of personal conduct that cannot be enforced by law, but which are indispensable traits for democratic citizenship." ${ }^{\text {72) }}$ Problems with the marital family, therefore, are clearly seen as problems for democracy, justifying legal and political responses. ${ }^{73)}$

Rights and Family Law in the United States During the 20th Century, 88 CALIF. L. R. 2017, 2076 (2000).

72) See Council on Civil Society, A Call to Civil Society: Why Democracy Needs Moral TRUTHS 7 (1998).

73) The National Commission on Civic Renewal has sponsored a series of scholarly working papers and created an Index of National Civic Health. NATIONAL Commission ON CiviC Renewal, a Nation of Spectators: How Civic Disengagement Weakens America and What We CAN Do AbOUt It (1998). 
Much of their attention is focused individual responsibility. As citizens, we are certainly seen to be a much diminished group who

place[s] less value on what we owe others as a matter of moral obligation and common citizenship; less value on personal sacrifice as a moral good; less value on the social importance of respectability and observing the rules; less value on restraint in matters of pleasure and sexuality; and correspondingly greater value on self-expression, selfrealization and personal choice. ${ }^{74)}$

A report prepared by a group of academics organized as the Commission of Civic Renewal, concluded where it began, with a "call to [more responsible, old fashioned] citizenship."75) The family, labeled "the seedbed of virtue," is viewed as citizen producing. ${ }^{76)}$ Families are "crucial sites for shaping character and virtue, they provide vivid models of how to behave in the world, and they help connect both children and adults to their neighborhoods and communities." 77 )

In fact, the report states that a major failing of the self-indulgent citizen is the rejection of the institution of marriage. This behavior is particularly significant since marriage is central to the civil societarian's concept of "the family." The Commission's report is very clear that the family at the center of civil society is a traditionally populated one-a nuclear or marital family. The Commission's conclusion about the decline of the family is evidenced solely through measuring the incidence of divorce and non-marital births. ${ }^{78)}$ The report is full of assertions about the inferiority of the non-marital family's child raising ability. The authors recommend that the nation make a commitment to the proposition that "every child should be raised in an intact

74) Id. at 7.(citing Daniel Yankelovich, How Changes in the Economy Are Reshaping American Values, in Values and Public Policy (Henry J. Aaron, et al. eds., 1994)). This seems to be particularly ironic given that the implications on civic health of current economic arrangements are not seriously considered in the Commission's Final Report.

75) COUNCIL ON Civil SOCIETY, supra note 72, at 20.

76) National Commission on Civic Renewal, supra note 73, at 7.

77) Council on Civil SOCIETY, supra note 72, at 13.

78) Id. at 24 . 
two-parent family whenever possible."79) This focus on form, to the exclusion of other aspects of family, assumes that form determines function. ${ }^{80)}$ Its effect is to provoke law reform proposals seeking to make divorce more difficult and to deter single parenthood.

\section{Legal Manifestations of Backlash}

There have been hints of a counter-revolution, particularly in regard to nofault divorce. ${ }^{81)}$ Arguments are made that no-fault divorce has prompted a rush to dissolution in which whims are given substance and salvageable marriages dissolved. ${ }^{82}$ In recent years there have been numerous attempts to make divorce more difficult to obtain. Successful on a legislative level at least initially was the "covenant marriage" ${ }^{\text {"83) }}$ movement in which a more serious and fault based system to govern divorce has been set up as an alternative to the no-fault model (often labeled "marriage-lite). ${ }^{84)}$ Louisiana was the first state to adopt the "covenant marriage" in 1997 which allows couples to choose a more binding marital contract-a number of states have followed suit. ${ }^{85)}$

More recently, the Chief Justice of the Georgia Supreme Court, Leah Ward Sears, is part of a movement to promote marriage and decrease family

79) Id.

80) The Council ON Civil Society writes that "the steady break-up of the married couple child-raising unit (is) the leading propeller of our overall social deterioration ..." supra note 72, at 18 .

81) Joel A. Nichols, Louisiana's Covenant Marriage Law: A First Step Toward A More Robust Pluralism in Marriage and Divorce, 47 EмоRу L. J. 929, 931 (1998).

82) Council on Civil Society, supra note 72, at 18.

83) Joel A. Nichols, Multi-tiered Marriage: Ideas and Influences from New York and Louisiana to the International Community, 40 VANDERBILT Journal of TRANSNATIONAL LaW 48-49 (2007).

84) In Arizona, Arkansas, and Louisiana couples may now enter into a covenant marriage contract, which encourages counseling for married couples in crisis and limits reasons for divorce. States that considered passing a covenant marriage law include: Nebraska, Ohio, Alabama, California, Georgia, Indiana, Kansas, Minnesota, Mississippi, Missouri, Oklahoma, South Carolina, Tennessee, Virginia, Washington, West Virginia, and Alaska. See Heather Flory, I Promise to Love Honor Obey, and not Divorce You: Covenant Marriage and the Backlash Against NoFault Divorce, 34 FAMILY LAW QuARTERLY 133 (2000).

85) See Joel A. Nichols, supra note 83; Joe Laconte, I'll Stand Bayou, Policy Review, May 1, 1998 , at 30 . 
fragmentation. The movement she is a part of claims that family fragmentation negatively impacts children and the court system. ${ }^{86)}$ According to the National Fatherhood Initiative ("The Initiative") Georgians are more supportive of marriage as a whole than the nation and responded in a recent survey that they believe married people with children ought to stay together and couples should not be able to get a divorce without a reason. ${ }^{87}$ In the same survey Georgians expressed support for requiring pre-marriage counseling and stating that society would be better off if divorces were harder to get, but the survey never queried whether the participants about increasing regulation of divorce and pro-marriage legislation. ${ }^{88)}$

There also have been some campaigns to rewrite or repeal no-fault divorce laws. The first serious attempt occurred in 1996 in Michigan. ${ }^{89)}$ The most recent attempt was in Virginia in 2007-2008. ${ }^{90)}$ These attempts at reform target the unilateral nature of the no-fault divorce process, requiring the consent of both spouses before access to divorce would be granted. The rationale advanced is that no-fault is no more than legalized desertion unless there are attempts at reconciliation and both spouses agreed that the marriage was irretrievably broken

It is apparent that significant numbers of Americans view no-fault divorce as inappropriate. For both secular and religious reasons the arguments are that the legal rules that make divorce readily available undermining the institution. They may do so because they invalidate the idea that marriage represents a life-long commitment and alter the naturally received gendered

86) Commission on Children, Marriage and Family Law \& the Institute for American Values, 2008 Summit on Children, Marriage and Family Law Program (Nov. 19, 2008). The program notes that "Children born out of wedlock are more likely to live in poverty, be incarcerated later in life, suffer from physical and sexual abuse, abuse alcohol and drugs, and engage in early sexual activity and premarital child bearing" and that family law cases "outnumber not only all other civil cases, but also all felony and misdemeanor cases combined."

87) Georgia Family Council and the National Fatherhood Initiative, With this Ring: A Survey of Marriage in Georgia (2005), http://www.georgiafamily.org/upload/With\%20This\%20RingGeorgia.pdf.

88) $I d$.

89) Dana Milback, The Blame Game: No-Fault Divorce is Assailed in Michigan, and Debate Heats Up, WALL St. J., Jan. 5, 1996, at A1.

90) Lynne Marie Kohm, Family and Juvenile Law, 42-2 U. Rich. L. Rev. (Annual Survey of VIRGINIA LAW) 417, 436 (2007). 
roles of husband and wife, father and mother. To others, the harm to children forms the battle cry. For many Americans, however, the nation confronts a crisis situation in which marriage is more tenuous and weaker as an institution than it was in the mid twentieth century. 